\title{
Prevalence and economic loss of bovine tuberculosis in a municipal abattoir, Abeokuta Southwestern Nigeria
}

*Oluwasile. B. B., Awoyomi. O.J. and Kehinde, O. O.

Department of Veterinary Public Health and Reproduction, College of Veterinary Medicine, Federal University of Agriculture PMB 2240, Abeokuta, Nigeria.

*Corresponding author: : oluwasilebb@funaab.edu.ng,

babafela@yahoo.com

\begin{abstract}
A 12 month cross-sectional study was carried out at Lafenwa Abattoir Abeokuta, Southwestern Nigeria from July, 2011 to June, 2012. This was to determine the prevalence and economic loss of bovine tuberculosis in this abattoir. A total of 928 cases of bovine tuberculosis out of 52,273 cattle slaughtered during this period were condemned, representing a total prevalence of $1.78 \%$ (95\% CI: 1.31-2.14\%). Typical tuberculous lesions were found in the Lung, Liver and Spleen, higher rate of organ condemnation was observed in the lung followed by liver and spleen. There was statistically significant difference in rate of organ condemnation $(P<0.05)$. The monthly prevalence and sequence plot revealed an epidemic tendency for bovine tuberculosis during this period and there was statistically significant difference between prevalence of bovine tuberculosis and seasonal occurrence. An estimated total loss of N1.2 million (US\$7,367) due to bovine tuberculosis was observed in this abattoir for the year. It was concluded that bovine tuberculosis is prevalent with epidemic tendency in cattle destined for human consumption, also with attending serious public health implications and huge loss to both the butchers and national economy.
\end{abstract}

Keywords: Bovine tuberculosis, Prevalence, Economic loss, Lafenwa abattoir

\section{Introduction}

Meat inspection as part of the veterinary public health activities ensures the delivery of hygienically processed meat for public consumption while preventing the transmission of infectious and zoonotic diseases to humans (Alonge and Fasanmi, 1979). The activity also provides vital data and valuable information on the incidences and prevalence of animal diseases and conditions within any country (Phiri, 2006). The abattoir is a source of invaluable information on the incidence of animal diseases and conditions including those of zoonotic importance such as tuberculosis (Cadmus and Adesokan, 2009).

Bovine Tuberculosis (BTB) is one of the seven most neglected endemic zoonoses in the world, particularly in developing countries (WHO, 2006). In developing countries, animal tuberculosis is still prevalent and is responsible for significant economic loss in animal production. Indeed, the disease induces high animal morbidity and mortality that eventually reduces the financial capital and increases production costs and also account for human health problems and even deaths (Cosivi et al., 1998). According to literature, approximately $85 \%$ of the cattle and $82 \%$ of the human population of Africa live in areas where animal tuberculosis is either partly controlled or uncontrolled (Ayele et al., 2004). In contrast however, only a few African countries have applied disease control measures as part of "test and slaughter" strategy and consider the disease as notifiable (Cosivi et al., 1998). Despite 
this, in most developing countries pasteurization is not well practiced and therefore, $10 \%$ to $15 \%$ of human tuberculosis is considered to be caused by M. bovis (Thoen et al., 2009).

In Nigeria, the endemic nature of bovine tuberculosis (BTB) has been reported judging from the prevalence from various abattoirs in the country (Igbokwe et al., 2001: Cadmus et al., 2008; Cadmus and Adesokan, 2009; Adamu et al., 2011). However, to date, there is dearth of useful information on economic evaluation on condemned cases of bovine tuberculosis in Nigeria. Therefore, this study is with a view to evaluating the prevalence and possible economic implications associated with condemnations due to bovine tuberculosis at a municipal abattoir in Abeokuta, Southwestern Nigeria during routine meat inspection.

\section{Materials and Methods}

Study location: The study was carried out in Lafenwa abattoir, which is the major abattoir in Abeokuta. The abattoir is located in Abeokuta North Local Government area, Abeokuta, Ogun State in South-west Nigeria, situated at $7^{\circ} 9^{\prime} 39^{\prime \prime} \mathrm{N}, 3^{0} 20^{\prime} 54^{\prime \prime} \mathrm{W}$, in the rainforest vegetation zone of Nigeria (Google Earth, 2006).

Study Design: A 12 month cross-sectional study was carried out at Lafenwa Abattoir from July, 2011 to June, 2012 to determine an annual prevalence of tuberculosis in this abattoir. Post slaughter examination involved visual examination of carcasses and organs with keen attention being directed to viscera organs. Evidence of pathological cases of tuberculosis in the visceras during this period was based on post-mortem examination of characteristic lesions of tuberculosis at meat inspection as earlier described (Awah-Ndukum et al., 2007).
Seasonal Variation: The months of the year were divided into two periods, i.e. the dry season (April to September) and the wet season (October to March), and the Chisquare $(\chi 2)$ test was applied to investigate associations between prevalence and season. The monthly oscillation was analyzed graphically, as plots of the monthly prevalence over the year evaluated.

Economic loss evaluation: The economic loss due to tuberculosis was assessed adopting the method by Ibironke and Fasina, 2010. This was carried out by considering the retail market prices of an average cattle liver, lung, and spleen and total weight loss for both total and partial condemnation of lung, liver and spleen due to tuberculosis. The retail market prices of an average size liver, lung and spleen was determined through interaction with the butchers in Lafenwa abattoir. For cases of partial condemnation, average value of the affected organs were used as reported by Ibironke and Fasina, 2010 that partial condemnation often reduces the market value of the remaining organ to about half of its original value as consumers see such tissues as being inferior and so offer less price for it. The average weights of the organs were determined using standard weighing scale. The information was subjected to mathematical computation using the formula set by Ibironke and Fasina, 2010.

Statistical Analysis: Data generated from postmortem meat inspection for cases of tuberculosis were recorded in Microsoft Excel 2003 program and analyzed using Statistical Packages for Social Sciences (SPSS 16). Descriptive statistics was used to determine the level of organs condemnation rates due to tuberculosis which was defined as proportion of condemned organs to the total number of 
organs examined. Seasonal variation and comparison of rate of condemnation due to tuberculosis between organs were determined using Chi-square test.

\section{Result}

A total of 52,273 cattle heads were slaughtered at Lafenwa abattoir during the one year period with an average slaughter of 4,356 cattle per month. A total of 928 cases of bovine tuberculosis were condemned representing a total prevalence of $1.78 \%$ (95\% CI: $1.31-2.14 \%)$. Average monthly prevalence of $1.72 \%$ was observed and varied from $0.79 \%$ in May, 2011 to $2.64 \%$ in December, 2011.

Organs specific prevalence was $1.56 \%$ (95\% CI: $1.19-1.95 \%), 0.18 \%$ (95\% CI: $0.12-0.23 \%)$ and $0.04 \%$ (95\% CI: $0.02-$ $0.06 \%$ ) for Lung, Liver and Spleen respectively. Cases of pulmonary tuberculosis varied from $0.6 \%$ in May, 2011 to $2.43 \%$ in December, 2011 with an average prevalence of $1.57 \%$ per month. Hepatic tuberculosis varied from $0.04 \%$ in September, 2011 to $0.36 \%$ in November, 2011 with an average prevalence of $0.18 \%$ per month. While splenic tuberculosis varied from $0.00 \%$ in July, 2011 to $0.007 \%$ in February, 2012 with an average prevalence of $0.04 \%$ per month. The rate of organ condemnation as presented in Table 2 , revealed a statistically significant difference in organ condemnation $\left(\mathrm{X}^{2}=\right.$ 133.66; $\mathrm{P}<0.05$ ).

The monthly prevalence and sequence plot revealed an epidemic tendency for bovine tuberculosis particularly pulmonary tuberculosis and to lesser extent hepatic tuberculosis (Figure 2). The seasonal variation in prevalence revealed greater prevalence during the dry season (April September) compare to wet season (Table 3 ) and there was statistical significance difference between the season and prevalence of tuberculosis $\left(\mathrm{X}^{2}=16.19\right.$; $\mathrm{P}<0.05$ ).

Table 4 shows the total weight loss of different organs and associated cost implications due to bovine tuberculosis. An estimated total loss of N1.2 million (US\$7,367) due to bovine tuberculosis was observed.

\section{Discussion}

The World Organization for Animal Health (OIE) considers BTB to be an important zoonotic disease with a socioeconomic and public health impact that affects the international trade of livestock and animal products. The disease has a worldwide distribution including Africa, and in many countries, bovine tuberculosis remains a major chronically infectious disease among cattle and other domesticated animals (Ayele et al., 2004). The prevalence of bovine tuberculosis has been reported in various areas in Nigeria. The prevalence rate $(1.78 \%)$ of BTB observed in this study is higher than $0.55 \%$ prevalence reported by Ameen et al., 2008, 1.1\% reported by Bikom and Oboegbulem, 2007 and Nwanta et al., 2011 but lower than $4.73 \%$ and 3.4\% reported by Hena et al., 2012 and Opara et al., 2012 respectively.

The distribution of the lesions in various organs indicated that the lung was the most affected followed by liver and spleen, similar trend of distribution of affection in lung followed by liver have also been reported by Opara et al., 2012. The occurrence of lesions in the different major organs suggests the possible route of transmission of the BTB, as observed in this study, is possible to suggests that, the principal mode of transmission of the aetiological agent of BTB is through inhalation route rather than ingestion as observed and reported by Radostitis et al., 1994, Ameen et al., 2008 and Opara et al., 
Prevalence and economic loss of bovine tuberculosis in a municipal abattoir

Table 1: Monthly and Organs Prevalence of Bovine Tuberculosis in a Municipal Abattoir, Southwestern, Nigeria.

\begin{tabular}{|c|c|c|c|c|c|c|c|c|c|c|c|}
\hline \multirow[b]{2}{*}{ MONTH } & \multirow[b]{2}{*}{ TS } & \multirow[b]{2}{*}{ TP n (\%) } & \multicolumn{2}{|l|}{ LUNG } & \multicolumn{3}{|c|}{ LIVER } & & \multicolumn{2}{|l|}{ SPLEEN } & \multirow[b]{2}{*}{$\begin{array}{l}\text { TOTAL } \\
\mathrm{n}(\%)\end{array}$} \\
\hline & & & $\mathrm{TC} n(\%)$ & $\mathrm{PC} n(\%)$ & $\begin{array}{l}\text { TOTAL } \\
\mathrm{n}(\%)\end{array}$ & $\mathrm{TC} n(\%)$ & $\mathrm{PC} n(\%)$ & $\begin{array}{l}\text { TOTAL } \\
\mathrm{n}(\%)\end{array}$ & $\mathrm{TC} n(\%)$ & $\mathrm{PC} \mathrm{n}(\%)$ & \\
\hline JULY & 3832 & $61(1.59)$ & $\begin{array}{l}17(0.44) \\
\end{array}$ & $38(0.99)$ & $55(1.44)$ & $1(0.03)$ & $5(0.13)$ & $6(0.16)$ & $0(0.00)$ & $0(0.00)$ & $0(0.00)$ \\
\hline AUGUST & 4120 & $79(1.92)$ & $25(0.61)$ & $42(1.02)$ & $67(1.63)$ & $6(0.14)$ & $3(0.07)$ & $9(0.21)$ & $0(0.00)$ & $3(0.07)$ & $3(0.07)$ \\
\hline SEPT & 4618 & $54(1.17)$ & $20(0.43)$ & $28(0.61)$ & $48(1.04)$ & $2(0.04)$ & $2(0.04)$ & $4(0.04)$ & $2(0.04)$ & $0(0.00)$ & $2(0.04)$ \\
\hline OCT & 4467 & $114(2.55)$ & $59(1.32)$ & $47(1.05)$ & $106(2.40)$ & $4(0.09)$ & $2(0.05)$ & $6(0.14)$ & $2(0.05)$ & $0(0.00)$ & $2(0.05)$ \\
\hline NOV & 4239 & $106(2.5)$ & $28(0.66)$ & 61(1.44) & $89(2.10)$ & $9(0.21)$ & $6(0.14)$ & $15(0.36)$ & $0(0.00)$ & $2(0.05)$ & $2(0.05)$ \\
\hline DEC & 5072 & $134(2.64)$ & $40(0.79)$ & $83(1.64)$ & $123(2.43)$ & $1(0.02)$ & $7(0.14)$ & $8(0.16)$ & $1(0.02)$ & $2(0.04)$ & $3(0.06)$ \\
\hline JAN & 3352 & $80(2.39)$ & $22(0.66)$ & $48(1.43)$ & $70(2.09)$ & $2(0.06)$ & $8(0.24)$ & $10(0.30)$ & $0(0.00)$ & $0(0.00)$ & $0(0.00)$ \\
\hline FEB & 4366 & $87(1.2)$ & $27(0.62)$ & $49(1.12)$ & $76(1.70)$ & $2(0.05)$ & $6(0.14)$ & $8(0.19)$ & $2(0.05)$ & $1(0.02)$ & $3(0.07)$ \\
\hline MAR & 4511 & $72(1.6)$ & $28(0.62)$ & $35(0.78)$ & $63(1.40)$ & $2(0.04)$ & $6(0.13)$ & $8(0.17)$ & $0(0.00)$ & $1(0.02)$ & $1(0.02)$ \\
\hline APR & 3987 & $39(1.00)$ & $16(0.40)$ & $16(0.4)$ & $32(0.80)$ & $2(0.05)$ & $3(0.08)$ & $5(0.13)$ & $0(0.00)$ & $2(0.05)$ & $2(0.05)$ \\
\hline MAY & 5182 & $41(0.79)$ & $24(0.46)$ & $8(0.15)$ & $32(0.60)$ & $2(0.04)$ & $6(0.12)$ & $8(0.16)$ & $1(0.02)$ & $0(0.00)$ & $1(0.02)$ \\
\hline JUNE & 4527 & $61(1.34)$ & $32(0.71)$ & $22(0.49)$ & $54(1.20)$ & $3(0.07)$ & $2(0.04)$ & $5(0.11)$ & $1(0.02)$ & $1(0.02)$ & $2(0.04)$ \\
\hline TOTAL & 52273 & $928(1.78)$ & $338(0.65)$ & $477(0.91)$ & $815(1.56)$ & $36(0.07)$ & $56(0.11)$ & $92(0.18)$ & $9(0.02)$ & $12(0.02)$ & $21(0.04)$ \\
\hline MEAN & 4356.1 & $77.3(1.72)$ & $28.2(0.64)$ & $39.75(0.93)$ & $67.92(1.57)$ & $3(0.07)$ & $4.67(0.11)$ & $7.67(0.18)$ & $0.75(0.02)$ & $1(0.02)$ & $1.75(0.04)$ \\
\hline
\end{tabular}

TS- Total Slaughter, TP- Total Prevalence, TC-Total Condemnation, PC-Partial Condemnation, n-Number

Table 2: Organs Condemnation rate due Bovine Tuberculosis in a Municipal Abattoir, Southwestern, Nigeria

\begin{tabular}{lllll}
\hline Organ & Total Condemnation (TC) & $\begin{array}{l}\text { Partial } \\
\text { Condemnation } \\
(\mathrm{PC})\end{array}$ & Total & $\begin{array}{l}\text { Organ condemnation rate } \\
(\%)\end{array}$ \\
\hline Lung & $338(0.65)$ & $477(0.91)$ & $815(1.56)$ & 87.64 \\
Liver & $36(0.07)$ & $56(0.11)$ & $92(0.18)$ & 10.11 \\
Spleen & $9(0.02)$ & $12(0.02)$ & $21(0.04$ & 2.25 \\
Total & $383(0.74)$ & $545(1.04)$ & $928(1.78)$ & 100.0 \\
\hline \multicolumn{5}{c}{ Organ condemnation: $\chi 2=133.66 ; \mathrm{P}<0.05$}
\end{tabular}


Table 3: Seasonal distribution in Prevalence of Bovine Tuberculosis in a Municipal Abattoir, Southwestern, Nigeria

\begin{tabular}{lll}
\hline Season & Number of cattle Slaughtered & $\begin{array}{l}\text { Number } \\
\text { positive }(\%)\end{array}$ \\
\hline Dry (April- September) & 26266 & $335(7.81)$ \\
Wet (October - March) & 26007 & $593(12.91)$ \\
\hline$\chi^{2}=16.19 ; \mathrm{P}<0.05$ &
\end{tabular}

Table 4: Economic evaluation of Condemned organs due to Bovine Tuberculosis in a Municipal Abattoir, Southwestern, Nigeria

\begin{tabular}{|c|c|c|c|c|c|c|c|c|}
\hline Organs & $\mathrm{TC}$ & $\begin{array}{l}\text { Weight } \\
(\mathrm{Kg})\end{array}$ & $\begin{array}{l}\text { Cost } \\
\text { Implication } \\
\text { (Naira) }\end{array}$ & $\mathrm{PC}$ & $\begin{array}{l}\text { Weight } \\
(\mathrm{Kg}) \quad[50 \% \\
\text { of } \\
\text { approximate } \\
\text { weight is } \\
\text { lost totally] }\end{array}$ & $\begin{array}{l}\text { Cost Implication } \\
\text { (Naira) [Total cost } \\
\text { of condemnation= } \\
\text { Average price plus } \\
50 \% \text { of average } \\
\text { price] }\end{array}$ & $\begin{array}{l}\text { Total loss } \\
\text { (Naira) }\end{array}$ & $\begin{array}{l}\text { Total loss } \\
\text { (US } \\
\text { Dollars) }\end{array}$ \\
\hline Lung & 338 & 676 & 405,600 & 477 & 477 & 429,300 & 834,900 & $5,296.78$ \\
\hline Liver & 36 & 144 & 144,000 & 56 & 112 & 168,000 & 312,000 & $1,979.39$ \\
\hline Spleen & 9 & 10.8 & 7,203 & 12 & 7.2 & 7,200 & 14,403 & 91.38 \\
\hline Total & 383 & 830.8 & 556,803 & 545 & 596.2 & 604,500 & $1,161,303$ & $7,367.55$ \\
\hline $\begin{array}{l}\mathrm{TC}=\text { Unit } \\
\mathrm{PC}=\text { Unit } \\
\text { Average } \mathrm{w} \\
\text { Average } \mathrm{w} \\
\text { Average } \mathrm{w} \\
\text { Conversio }\end{array}$ & $\begin{array}{l}\text { ght of } \\
\text { ght of } \\
\text { ght of }\end{array}$ & $\begin{array}{l}\text { totally con } \\
\text { artially co } \\
\text { ing is take } \\
\text { ver is take } \\
\text { oleen is tal }\end{array}$ & $\begin{array}{l}\text { mned } \\
\text { demned } \\
\text { o be } 2 \mathrm{~kg} \text { at } \mathrm{N} 66 \\
\text { o be } 4 \mathrm{~kg} \text { at } \mathrm{N} 1 \\
\mathrm{l} \text { to be } 1.2 \mathrm{~kg} \text { at } \\
157.62=\mathrm{US} \$ 1\end{array}$ & $\begin{array}{l}\mathrm{kg} \\
70 / \mathrm{kg}\end{array}$ & . & & & \\
\hline
\end{tabular}

2012. Bovine tuberculosis as observed in this study appeared primarily in the pulmonary form, pulmonary TB lesions were empirically indicative of BTB prevalence among slaughtered cattle, a finding which have also been observed and reported by Edelsten,1996 and Igbokwe et al., 2001. The prevalence rate of $1.56 \%$ observed for pulmonary TB in this study is lower than $2.8 \%$ reported by Igbokwe et al., 2001.

The monthly prevalence illustration revealed the variations in the occurrence and trend of BTB cases in different organs and during the period of study. The occurrence of BTB revealed an epidemic tendency and this suggest the need for control measures to reduce the number of bovine TB cases and to prevent the spread of the disease to human populations. The highest prevalence of BTB recorded in December, 2011, may be due to seasonal influence and possibly increase in number of cattle slaughtered in the month of December compared to other months due to festive seasons of Christmas and New Year celebrations. Seasonal BTB prevalence rate revealed higher prevalence during the dry season compare to wet season and a strong association between the occurrence of tuberculosis lesions and seasonal distribution. This may probably suggest that season has effect on transmission rate of BTB. This finding have also been observed by Bikom and Oboegbulem (2007) in Cross river State abattoir, but 
differs from Ameen et al., (2008) and Nwanta et al., (2011) who observed no association between occurrence of tuberculosis lesions and seasonal distribution.

Organ condemnation due to BTB as seen in this study account for close to N1.2 million (US\$7,367.55) huge economic losses to the butchers/traders especially in Nigeria where there is no compensation scheme available to the butchers/traders for condemned organs. This also impact negatively on the economic returns of Nigeria especially in this study where a single abattoir recorded close to N1.2 million (US\$7,367.55) losses for condemnation of organs due to a single disease as BTB. Estimating and extrapolating this loss for all abattoirs in the 36 States and Federal Capital Territory of the Nation will amount to huge economic loss and negative effect on gross domestic product of the country especially for a lowincome food deficient country [LIFDC] like Nigeria (World Bank, 2006).

In conclusion, Bovine tuberculosis is prevalent in cattle destined for human consumption with serious public health implications; also BTB is endemic with epidemic and huge economic loss tendencies. Thus, information about zoonotic diseases and their potential impact on human health should be disseminated appropriately in Nigeria especially on the role of cattle in epidemiology of human tuberculosis. There is need for public awareness on possibilities of zoonotic spread to human with very devastating effect when considering the epidemic of HIV/AIDS in the country, there is also the need for Nigerian government to employ qualified, competent personnel to implement meat inspection measures, and also equip them with functional laboratories and facilities for effective diagnoses during meat inspection exercises. On the other hand, farmers/butchers should be adequately compensated by appropriate authority for their condemned animal carcass(es) which will ultimately encourage co-operation between farmers and government agencies to prevent tuberculous products from entering the market for human consumption.

\section{Acknowledgement}

We appreciate the staffs of Veterinary Public Health division of Ministry of Agriculture and Natural Resources, Ogun State for their support and also the butchers of the abattoir for their cooperation during the course of study.

\section{References}

Adamu N. B., Ali E. G and Adamu J. Y. 2011. Bacterial and parasitic zoonoses encountered at slaughter in Maiduguri abattoir, Northeastern Nigeria. Veterinary World, 4 (10):437-443.

Alonge, D. O. and Fasanmi, E. F. 1979. A survey of abattoir data in northern Nigeria. Tropical Animal Health and Production 11: 57-62.

Ameen, S.A., Adedeji, O.S., Raheem, A.K., Leigh, O.O., Rafiu T.A. and Ige A.O. 2008. Current Status of Bovine Tuberculosis in Ogbomoso Area of Oyo State. Middle-East Journal of Scientific Research 3 (4): 207-210.

Awah-Ndukum, J., Tchoumboue, J. and Niba A.T., 2007. Current status of bovine tuberculosis and other pathological conditions at the SODEPA Douala abattoir, Dschang, Cameroon (1995-2003) Tropical Veterinarian, 25, 58-64.

Ayele W.Y., Neill S.D., Zinsstag J., Weiss M.G. and Pavlik I. 2004. Bovine tuberculosis: an old disease but a new 
threat to Africa. The International Journal of Tuberculosis and Lung Disease 8, 924-937.

Bikom, P.M. and Oboegbulem, S.I. 2007. Prevalence of suspected tuberculous lesions in cattle slaughtered in Cross River State Abattoirs, Nigeria Journal of Animal Production, 34(2): 301-305.

Cadmus S.I.B. and Adesokan H. K. 2009. Causes and implications of bovine organs/offal condemnations in some abattoirs in Western Nigeria. Tropical Animal Health Production 41:1455-1463.

Cadmus, S.I.B., Adesokan, H.K. and Awosanya A.E.J., 2008. Public health issues and observations made during meat inspection at Bodija Municipal Abattoir, Ibadan, Oyo state. Nigeria, Nigerian Veterinary Journal, 29(2): 43-47.

Cosivi O., Grange J.M., Daborn C.J., Raviglione M.C. and Fujikura T. 1998. Zoonotic tuberculosis due to Mycobacterium bovis in developing countries. Emerging Infectious Diseases 4: 59-70

Edelsten R.M., 1996. Tuberculosis in cattle in Africa - Control measures and implications for human health. In: Lindberg R. Ed., Veterinary medicine - Impacts on human health. Uppsala, Sweden, Sweddish University of Agricultural Sciences, p. 23-31.

$\begin{array}{lllllllllllllll}G & 0 & 0 & g & l & e & E & a & \mathbf{t} & \mathbf{h}, & \mathbf{2} & 0 & 0 & 6\end{array}$. http://www.google.earth

Hena, S. A., Tanimomo, B.K., Tarhyel, R., Ngbede, E.O., Oluwasina, O.O., Jagtap, G.P., Dhavale, M.C. and Dey U. 2012. A tentative case of tuberculosis detected at postmortem examination of animal carcasses slaughtered at some local slaughter slabs in north-western Nigeria. Scientific Journal of Agriculture 1(2)
27-32.

Ibironke, A. A. and Fasina F. O. 2010. Socio-economic implications of bovine liver rejection in a major abattoir in south-western Nigeria. Revista de Ciências Agrárias 33(2), 211-216.

Igbokwe I.O., Madaki I.Y., Danburam S., Ameh J.A., Aliyu M.M. and Nwosu C.O. 2001. Prevalence of Pulmonary Tuberculous Lesions in Cattle Slaughtered in Abattoirs in Northeastern Nigeria. Revue d'élevage et de medicine vétérinaire des pays tropicaux, 54 (3-4): 191-195.

Nwanta J. A., Umeononigwe C. N., Abonyi G. E. and Onunkwo J. I. 2011. Retrospective study of bovine and human tuberculosis in abattoirs and hospitals in Enugu State, Southeast Nigeria. Journal of Public Health and Epidemiology 3(7), 329336.

Office International des Epizooties. Código sanitario para los animales terrestres. Vol 2. Available from: http:// www.oie.int/es/normasin ternacionales/codigoterrestre/acceso-enlinea/

OIE Terrestrial Manual, 2009. Bovine tuberculosis, Chapter 2.4.7. Pp 1-16.

Opara, M. N., Nwaeze, C. N., Olaifa, A. K., Maxwell, J. A., and Okoli, I. C. 2012. Prevalence of Bovine Tuberculosis (BTB) in Imo State, Southeastern Nigeria. Journal of Tropical Medicine and Parasitology.35:14-21.

Phiri, A. M. 2006. Common conditions leading to cattle carcass and offal condemnation at three abattoirs in western province of Zambia and their zoonotic implication to consumers. Journal of the South African Veterinary Association 77: 28-32. 
Radostitis, O.M., Gay, C.C., and Blood, D.C. 1994. Veterinary Medicine: A text book of disease of Cattle, sheep, goats, pigs, and horses W.B. Saunder $\left(8^{\text {th }}\right.$ ed.) pp. $830-840$.

The World Bank 2006. World Bank List of Economies Available from http://www.iscb.org/pdfs/World $\% 20$ Bank\%20Classification $\% 20$ List $\% 20$ 2006.pdf

Thoen C.O., LoBue P., Enarson D.A., Kaneene J.B., de Kantor I.N. 2009. "Tuberculosis: a re-emerging disease of animals and humans, Veterinaria Italiana, 45: 135-181.

WHO 2006. The Global Plan to Stop TB, 2006-2015. Actions for life: towards a world free of tuberculosis. The International Journal of Tuberculosis and Lung Disease, 10: 240-241.

Yahoo Currency Converter 2008. A va i $1 \mathrm{a} \mathrm{ble} \quad \mathrm{f} \mathrm{rom}$ http://uk.finance.yahoo.com/currency / convert $\mathrm{mt}=1 \&$ from $=\mathrm{USD} \&$ to $=\mathrm{NGN}$

Received: $10 / 01 / 13$ Accepted: 15/08/13 